\title{
Assimetria e saliência: a relação entre iniciador/a e imitadores/as na circulação de bens industrializados entre os Wajãpi no Amapá
}

DOI

http://DX.DOI.ORG/

$10.11606 / 1678-9857$ RA. 2020.189649

\section{Camila Galan de Paula}

Universidade Federal do Vale do São Francisco | São Raimundo Nonato, PI, Brasil

camila.galan@univasf.edu.br

ORCID: https://orcid.org/0000-0002-7463-1409

RESUMO

PALAVRAS-CHAVE

Este artigo busca nova análise para dados de campo e interpretações anteriores sobre a circulação de produtos industrializados entre os Wajãpi no Amapá. O foco recai sobre a relação de tipo de imitador(a)-seguidores(as): os interlocutores em campo explicavam que algumas coisas eram amplamente compradas e usadas porque alguém teria comprado primeiro, e os demais, imitado esse iniciador. Em trabalhos anteriores, compreendi que tal processo poderia ser analisado à luz de discussões que estabelecem dois modos de circulação de mercadorias entre povos da América do Sul indígena, um relativo à magnificação de pessoas, outro à consanguinização e ao estabelecimento de relações simétricas. Aqui, busco reexaminar os dados à luz de interpretações das socialidades ameríndias que não partam de noções de propriedade e controle. Sugiro que a assimetria implicada no ato de iniciar uma moda possa ser entendida como a ocupação provisória de uma posição de "saliência".

ASYMMETRY AND SALIENCE: INITIATOR AND FOLLOWERS' RELATION IN THE INDUSTRIAL GOODS CIRCULATION AMONG THE WAJÃPI IN AMAPÁ (BRAZIL)

ABSTRACT This article re-analyses field data and former interpretations on the circulation of industrial goods among Wajãpi people in the Brazilian state of Amapá. The relation focused here is that of initiator-followers. Interlocutors in the field explained the acquisition of some goods by implying there is always an initiator who is followed by other in buying certain articles. I have formerly described this dynamic by associating Wajãpi explanations to discussions that state the existence of two ways of goods circulation among Lowland South American Indigenous peoples, one leading to magnification processes, another to kinship-making and symmetrical relations. This article re-examines initiator-followers process in the light of interpretations of Amerindian socialities that forgo notions of ownership and control. I suggest that the initiator of an action temporarily occupies a position of "salience".

Wajãpi, Amazônia, mercadorias, política ameríndia, consumo 


\section{INTRODUÇÃO: OS AMERÍNDIOS E SUAS COMPRAS}

Em minha primeira estada na Terra Indígena Wajãpi, no Amapá, iniciei a observação dos bens industrializados utilizados ali.' Percebi, de início, o uso de calcinhas com babados por muitas meninas pequenas, que ainda não trajavam saias. ${ }^{2}$ Perguntando sobre tais peças de roupa, explicaram-me assim a preferência generalizada: uma mulher foi a Macapá, gostou e comprou para sua filha. Quando voltou a sua aldeia, as demais mulheres gostaram e imitaram, comprando peças de roupa semelhantes. Ao longo da pesquisa de campo, o espraiamento do uso de algum tipo de objeto adquirido na cidade foi-me explicado assim: alguém fez ou comprou primeiro, os demais gostaram e imitaram (wãa) $)$.

Pretendo tratar do modo como os Wajãpi me explicaram essa dinâmica do(a) iniciador(a)-imitadores(as) ${ }^{3}$, com ênfase no uso de bens industrializados dado o foco principal de minha pesquisa. Nota-se, porém, que tal dinâmica não se restringe a bens da cidade, e lida com objetos e atividades diversos. Anteriormente, compreendi a explicação de meus interlocutores a partir do que João Dal Poz (2004: 185) denomina "dois princípios institucionais" operando na circulação de bens em sua etnografia junto aos Cinta-Larga. Outros antropólogos trabalhando na América do Sul indígena também explicam a circulação de bens a partir desses "dois vetores contraditórios" (Gordon, 2006b: 42; Grotti, 2007, 2013; Brightman, 2010). Em análises anteriores segui essa literatura e argumentei que a ação de iniciar o uso de um objeto na TI Wajãpi instaurava relações assimétricas, relacionadas ao acúmulo de bens, por sugestão da bibliografia.

Neste artigo, proponho desvincular a lógica do iniciador-imitadores da noção de uma circulação diferenciadora de bens, fruto de um acúmulo prévio de bens ou de relações que permitam sua obtenção. O intuito deste trabalho, assim, é aproximar meus dados de abordagens das socialidades indígenas que não partam de noções de propriedade, poder e controle para compreender o caráter assimétrico de certas relações (Lima, 2005; Guerreiro, 2015; Perrone-Moisés, 2015; para além da América do Sul cf. Strathern, 1999). Provisoriamente, proponho que o iniciador wajãpi ocupe uma posição de "saliência" com relação aos imitadores, termo que desenvolvo ao longo do artigo. ${ }^{4}$ Com essa releitura de material de campo à luz de outras discussões, este artigo tem o intuito de contribuir para abordagem renovada da circulação de bens industrializados e dinheiro entre populações indígenas das terras baixas da América do Sul.

Iniciei a pesquisa junto aos Wajãpi buscando compreender o que os levava a comprar certos objetos na cidade em detrimento de outros e, a partir da percepção de que compravam coisas semelhantes, os motivos para o fazerem. Sutiãs de modelos semelhantes, calcinhas de babados para meninas pequenas, relógios de pulso de mesmo modelo, panelas de alumínio iguais, blusões de futebol de mesmo modelo (mas de distintos times), computadores portáteis idênticos... era sobre esses objetos, sobretudo, que conversava com meus interlocutores. Inspirada por outros trabalhos
1| Entre 2013 e 2017, estive por um total de sete mese na TI Wajãpi, realizando atividades de pesquisa de campo, de acompanhamento de professores indígenas e participando de formações para as mulheres. A pesquisa de campo propriamente dita foi realizada entre $2014 \mathrm{e}$ 2015, quando visitei doze das mais de 90 aldeias (somando as aldeias permanente $\mathrm{e}$ aquelas habitadas apenas na estação seca) em que viviam então os cerca de 1.200 habitantes da TI Wajãpi.

2 Em outros trabalhos (Paula, 2015; 2016) apresento de modo mais detalhado as vestes dos Wajãpi. Resumidamente: 0 traje masculino nas aldeias é a tanga de pano vermelho, kamisa pirã, outrora típica em toda a região das Guianas e de possível adoção pós-colonial (Gillin, 1948: 824; Van Velthem, 2003); já as mulheres usam saias do mesmo tecido, às vezes optando por panos estampados. À parte calcinhas, outras peças de roupa são pouco usadas. Alguns homens usam camisetas ou blusões, e camisetas podem ser vistas nas manhãs mais frescas também entre mulheres. Muitas mulheres usam sutiãs mas não todas e nem em todas as ocasiões ou locais. As roupas na cidade são marcadamente distintas das usadas nas aldeias.

3 | Nesta única vez e no título, deixo marcado que as modas podem ser iniciadas por mulheres ou por homens. Atividades ou objetos generificados serão imitados apenas por pessoas de mesmo gênero-explorei essa questão especificamente para o uso de roupas, em outro trabalho (Paula, 2016). Os Wajãpi explicavam-me esse processo dizendo que alguém imitou o outro; "iniciador" e "imitadores" são termos que eu mobilizo para facilitar a escrita.

4 | Opto pelo termo saliência - em que pese seu sentido popular de assanhamento-em detrimento de proeminência porque este último termo, em sentido figurado, denota superioridade. $\mathrm{O}$ termo "saliência" é usado em trabalhos de ciências cognitivas - diferentes vertentes da antropologia cognitiva inclusas 
sobre bens industrializados entre povos indígenas (Hugh-Jones, 1992; Howard, 2002; Van Velthem, 2002, 2010; Dal Poz, 2004; Cordon, 2006a; 2006b; Grotti, 2007; 2013; Ewart, 2013a; 2013b; Walker, 2013), buscava entender os modos de circulação desses objetos, bem como os critérios de seleção e comparação operados pelos Wajãpi na compra ou apreciação das coisas adquiridas na cidade.

A bibliografia sobre circulação de bens industrializados na América do Sul indígena, embora não seja vasta, é variada. Enquanto alguns autores avizinham suas discussões da antropologia econômica (Dal Poz, 2004; Brightman, 2010), outros recusam a pertinência de tal aproximação. É o caso de Cesar Cordon (2006), e foi o caminho que optei por seguir, em favor de aproximações com discussões regionais da América do Sul indígena. A principal desvantagem de tal opção se dá pela dificuldade de comparar as etnografias com relação aos dois modos de fazer circular mercadorias e dinheiro pelas redes indígenas, que na abordagem de Dal Poz (2004), remetem a discussões clássicas de Karl Polanyi. Por outro lado, e pensando a partir de Marilyn Strathern (1999), a vantagem de não vincular análises sobre outros povos à antropologia econômica e a discussões de propriedade está em pôr em questão a historicidade dos termos usados na tradução de conceitos estrangeiros. David Graeber, escrevendo sobre práticas que a antropologia vem entendendo como "consumo", lembra-nos que

[...] talvez devêssemos considerar que em muitas das sociedades que estudamos a produção de produtos materiais sempre foi subordinada à construção mútua de seres humanos, e que o que elas estão fazendo, ao menos parcialmente, é simplesmente insistir em continuar a agir desse modo, mesmo quando usam objetos manufaturados alhures. Em certos casos, isso pode levar a resistência autoconsciente ao - tanto quanto a uma adoção entusiástica igualmente autoconsciente do - consumo capitalista. Mas na maioria dos casos, ao menos eu suspeito, nossas questões e categorias são simplesmente irrelevantes (Graeber, 2011: 502, minha tradução)

Similarmente, para o caso da circulação de bens e das relações assimétricas que ela implica, talvez devêssemos suspeitar da inadequação ou mesmo da irrelevância de nossas categorias. É esse exercício que pretendo desenvolver aqui.

Retomo os casos em que a compra de mercadorias foi explicada a partir da lógica da imitação. Uma professora com quem conversei explicou-me que foi a primeira mulher a usar sutiã na TI Wajãpi:

\footnotetext{
Primeira vez que fui lá no [conjunto de aldeias wajãpi na Cuiana Francesa] Camopi, tem uma amiga minha e ela conversou comigo e disse 'você usa esse' e ela me levou na casa dela e ela deu para eu vestir o sutiã. [...] Depois eu uso, comprei um lá em Macapá para eu vestir. [...] Quando eu tinha treze anos. Aí depois eu fui lá no [conjunto de aldeias] Mariry, o pessoal falou para mim 'Por que você usa esse sutiã?' E eu falei para elas: 'Eu uso porque eu gosto, porque também eu fico bonita, eu vejo o pessoal
}

- (Lakoff, 1990; Boyer, 2000; Blount, 2011), antropologia perceptual (Washburn, 1999) e antropologia da arte (Cell, 1998). Esclareço que o termo "saliência" tal qual mobilizado neste artigo guarda com conceitos antropológicos dessas outras abordagens apenas uma relação de homonímia. Ao contrário do uso que essas outras vertentes fazem do termo "saliência" para se referir à percepção sensorial, uso o termo para tratar de um caráter assimétrico das relações sociais. 
lá do Camopi.' [...] Aí começou a usar, quem tem assalariado, esposa de assalariado. Quem não tem assalariado não usa, não tem como comprar. [...] Eu acho que o pessoal... eu não sei dizer... eu acho que eu que espalhei isso para as moças. Eu comecei. [...] Aí depois pessoal imitou, todo mundo, até mais velha. Até depois nós, quando nós fomos lá em Macapá, aí a gente compra kamisa wiri ${ }^{5}$, qual que vai combinar, compra também kamisa azul. [...] Quando eu uso sutiã com saia, acho que o pessoal acha bonito, pensa que vai vestir também igual eu. [novembro/2014]

Essa professora, assim, aprendeu um modo de se vestir, imitou o que viu nas aldeias da Guiana Francesa, pois tinha gostado. Outras mulheres, em seguida, imitaram-na.

Um morador da aldeia Kwapo'ywyry comentou comigo sobre a recente moda de comemorar aniversários. Contou-me que aprendeu com um motorista não indígena que faz fretes (transporte em carros ou caminhonetes) para Macapá. Este Ihe explicou que em aniversários compra-se um bolo, refrigerantes e balões. Meu interlocutor, dessa forma, decidiu comemorar o aniversário de um de seus filhos. A partir de então, outras pessoas em aldeias próximas passaram a comemorar aniversários, reservando dinheiro para comprar bolo e refrigerantes em vendas em um assentamento rural às margens da rodovia Perimetral Norte. Pelo que pude observar, tal moda estava restrita a aldeias mais próximas à estrada, onde há acesso diário a bens vendidos em vendas no assentamento ou por pessoas que entram de carro ou moto na TI para fazer comércio.

Um professor, o primeiro a enviar seus filhos para terminar a educação escolar em Macapá, disse-me que depois outras pessoas o teriam imitado e mandado os jovens para a capital amapaense. De fato, quando realizei meu trabalho de campo, muitas famílias que contavam com aposentados ou assalariados enviavam filhos e netos para estudar em Macapá e, mais recentemente, em Pedra Branca do Amapari, seja na sede do município, seja em comunidades rurais. Na época, ter filhos estudando na cidade parecia algo importante de ser realizado.

Contaram-me também da primeira mulher a comprar um telefone celular, logo imitada. Também, do único homem a ter um carro - na realidade, oficialmente pertencente a uma das associações dos Wajãpi; outros estariam já se organizando para comprar um automóvel, inclusive tendo se inscrito em cursos de autoescolas. ${ }^{6}$

Os exemplos arrolados acima bastam para seguirmos com a discussão. Prossigo apresentando os dois modos de circular mercadorias na América do Sul indígena, de acordo com a bibliografia sobre o tema. Em seguida, introduzo temas correlatos e imbricados nessa dinâmica: inveja, fazer preconceito, desigualdade, disputa, generosidade. Justamente com a questão da generosidade, voltamos a um tema clássico nas terras baixas sul-americanas: a relação entre chefia e generosidade, para prosseguir com críticas a pressupostos de controle e propriedade para compreensão das socialidades ameríndias. A partir daí, será possível retornar à ideia de imitação e de iniciadores entre os Wajãpi. $\mathbf{5}$ | Tecidos estampados usados para saias. Foi também com mulheres do Camopi que mulheres da TI Wajãpi aprenderam a usar saias de panos estampados, kamisa wiri.

6| Particular, "o meu particular" é um modo de falar daquilo que não é coletivo; é aquilo que se refere a uma pessoa ou a sua família. Dominique Gallois (2002) apresenta essa distinção operada pelos Wajãpi no âmbito das políticas de geração de renda implementadas pelo Centro de Trabalho Indigenista nos anos 1990. No caso do carro, embora pertencente a uma associação, este era tido como particular de alguém. Marina Vanzolini (2018) apresenta sobre os Aweti um caso que envolve justamente uma caminhonete: doada para a comunidade, ela era usada pelo chefe como se fosse patikulá (o neologismo fo desenvolvido por Marina Novo [2017] para pensar lógicas de posse associadas à circulação de mercadorias entre os Kalapalo). Não investi esforços em compreender possíveis novas lógicas de posse associadas à circulação desses bens, como faz Novo (2017) e retoma Vanzolini (2018). 


\section{A CIRCULAÇÃO DE BENS INDUSTRIALIZADOS NA AMÉRICA DO SUL INDÍGENA: UMA DISCUSSÃO BIBLIOGRÁFICA}

A bibliografia sobre a circulação de mercadorias na América do Sul indígena indica a existência de dois modos de circulação de objetos. Cesar Cordon (2006a; 2006b) e João Dal Poz (2004) formulam de modo explícito essa questão, este vinculando sua discussão à antropologia econômica de viés substantivista, aquele rechaçando o diálogo com a antropologia econômica.

De acordo com Dal Poz (2004), a abordagem substantivista da economia de K. Polanyi compreende que a organização de produção e distribuição de bens (atividades econômicas) garantiria a integração social por meio de mecanismos de reciprocidade, redistribuição e troca mercantil. A reciprocidade referir-se-ia a trocas simétricas enquanto à "redistribuição, através da qual se cumprem as obrigações entre um chefe e seus súditos, corresponde o modelo da centralidade, baseado na coleta, no armazenamento e na partilha de bens e serviços" (Dal Poz, 2004: 33). Estabelece sua etnografia em diálogo com esse referencial teórico.

O chefe-de-casa (zapivaj) cinta-larga possui características comumente associadas aos chefes ameríndios: apazigua conflitos, inicia uma aldeia, começava empreendimentos guerreiros, é anfitrião de festas, é generoso doador de alimentos. É com relação a esse último ponto que Dal Poz situa o caráter redistributivo da posição de chefia: não basta querer ser chefe e ser iniciador de atividades, há determinações sociológicas e produtivas que se impõem. Uma "vasta parentela ou um vínculo hereditário renomado" (2004: 162) são importantes e para "consolidar ou estender o prestígio e a influência, um zapivaj direciona seus esforços no sentido de angariar mais recursos e benefícios, tanto os que provêm da produção interna quanto os capturados alhures, dos quais necessita se deseja assistir um número crescente de seguidores" (2004: 158). Assim, é o chefe quem se incumbia de distribuir mercadorias que chegavam às aldeias em certas ocasiões, "como se a ele, em particular, coubesse o controle estrito do fluxo de bens e serviços entre o grupo social e o seu exterior" (2004: 185). Esse controle de bens, contudo, é sempre fugaz, posto que é à generosidade que ele visa atender.

A necessária generosidade do chefe, notada em tantos contextos ameríndios, precisa de um momento anterior de acúmulo de relações e de bens que permite, justamente, a generosidade posterior. De acordo com a etnografia de Dal Poz (2004), isso ocorre tanto nos contextos de rituais, quanto no contexto mais contemporâneo (décadas de 1980 e 1990) de circulação de dinheiro advindo da liberação pelos CintaLarga de atividades garimpeiras e madeireiras em seu território. Assim, cabe ao chefe a abertura de roça, construção da casa e mais recentemente, "a posse de carros, camionetas ou caminhões que servem ao vai-e-vem interminável de moradores à cidade" (Dal Poz, 2004: 169). A construção de casas de madeira, nas décadas anteriores à escrita da tese de Dal Poz, era prerrogativa do chefe. Prerrogativa custosa, no entanto, 
que implicava em negociações com madeireiros, liberação dessa atividade e construção de casas com o dinheiro arrecadado. A falta de casas de madeira podia provocar inclusive cisões nos grupos residenciais (2004: 166).

O chefe Cinta-Larga, assim, precisa ser generoso, e essa distribuição sob a forma de festas, casas e idas à cidade possui, na análise de Dal Poz, o caráter centralizador da redistribuição tal qual proposta por Polanyi. No entanto, esse tipo de troca não é o único que ocorre ali. As trocas simétricas ocorrem também cotidianamente nos grupos residenciais: famílias trocam carne e chicha. Há obrigatoriedade de generosidade entre consanguíneos e corresidentes. A não generosidade nesse tipo de relação é tida como uma afinização, uma quebra do ideal de convivência das aldeias.

Também na etnografia de Cordon (2006a; 2006b) entre os Xikrin do Cateté, habitantes do sul do Pará, é possível observar que os bens circulam a partir de "dois vetores contraditórios" (2006b: 42).? Nos anos 1980 a Cia. Vale do Rio Doce (CVRD) firmou um convênio compensatório com esses indígenas por conta de atividades mineradoras na Serra de Carajás e passou a pagar salários aos chefes xikrin. Segundo Cordon, o sistema hierárquico xikrin é refletido na estrutura dos salários de chefes, e "um modo de valorização qualitativa do prestígio e da preeminência política passou a ser constituído e expresso quantitativamente por meio de uma escala de salários" (Cordon, 2006a: 4). Entre os Xikrin, há diferença entre aqueles que têm nomes comuns (idji kakrit), e os que têm nomes bonitos (idji mejx). Esses nomes estão ligados ao sistema cerimonial e conformam um sistema de produção de valor; sua beleza, mejx, advém de sua origem externa, animal, e tem ligação com sistema de transmissão cerimonial. Há ainda a diferença entre as pessoas bonitas e as verdadeiramente bonitas, aquelas com nomes belos confirmados cerimonialmente. Patrocinar uma cerimônia de confirmação de nome, contudo, requer esforços para produção de alimento ritual. Assim, há uma correspondência entre a diferença daqueles com nomes verdadeiramente belos e a hierarquia política. Pessoas boas/belas (me mejx) são aquelas com parentelas grandes, cuja capacidade produtiva lhes assegura participação na confirmação de nomes cerimoniais, aprendizado de suas prerrogativas cerimoniais (nêkrêjx e krukràdjà), "aquisição de status, posições de prestígio, funções de chefia e... atualmente [...] concentração de salários (Gordon, 2006a: 7).

Assim como na etnografia de Dal Poz sobre os Cinta-Larga, percebe-se uma correlação entre capacidade produtiva e hierarquia entre pessoas. O sistema hierárquico xikrin reflete-se na estrutura de salários recebidos da CVRD. Para o antropólogo,

\footnotetext{
não se trata de uma nova elite, mas de uma mesma e antiga elite, mas que se vale hoje de outros signos de prestígio: não tanto os bens cerimoniais (cuja origem é considerada exógena), mas outro tipo de bem exógeno: o dinheiro e os produtos industrializados (2006a: 20).
}

Se por um lado os industrializados circulam ritual ou comumente de modo "diferencial" (Gordon, 2006b: 341), há outra modalidade de circulação: aquela que se liga ao idioma 
do parentesco, e que Cordon se refere como "tendência para coletivização" (2006b: 42). Assim como circulam alimentos prontos entre corresidentes, o mesmo passa a ser feito com relação aos industrializados, seja alimentos ou outros itens. Tais objetos "são incorporados na dinâmica social como parte de um processo geral de fabricação de pessoas [...] individuais" (2006b: 305) e coletivas. No âmbito desse tipo de relação de consumo dos bens industrializados, frisa-se discursivamente a igualdade e não a competitividade (2006b: 347).

Gordon ainda atenta à interrelação entre os dois "vetores contraditórios" de circulação de bens que, no contexto do endinheiramento e afluxo de mercadorias, levaria a uma inflação no sistema; os bens perdendo rapidamente seu caráter de conferir distintividade. Nota o autor que, com o aumento do afluxo de bens industrializados nas aldeias, mais gente passou a ter recursos para fazer cerimônias de confirmação de nomes belos; os rituais deixaram de ser restritos. Novos produtos "de luxo" podem ser adquiridos para a diferenciação, mas a demanda sempre crescente por novas mercadorias é "uma espécie de resposta dada pelo sistema de diferenciação xikrin diante do que me parece ser uma pronunciada aceleração de seu funcionamento (Gordon, 2006b: 402).

As duas etnografias apresentadas acima, assim, pensam a circulação de bens como um dos aspectos centrais para o estudo das socialidades ameríndias. $\mathrm{Na}$ instauração de relações simétricas entre corresidentes, ou assimétricas/hierárquicas entre chefes e aldeões, importam o controle e a circulação de bens. Em reflexões anteriores, compreendi que os comentários de meus interlocutores wajãpi sobre o iniciador e imitadores relacionavam-se a esses dois vetores de circulação. Como se o iniciador instaurasse uma relação assimétrica ao ser o primeiro a ter, por exemplo, um telefone celular. Já a imitação compreendi como sendo um movimento de simetrização das relações, posto que tornaria todos (ao menos os assalariados) portadores dos mesmos bens industrializados. Sigo sugerindo que a ação do iniciador é uma relação de instauração de assimetria, mas entendo-a como uma relação de "saliência" e não de controle ou posse de bens. A seguir, trato de inveja, ciúme, avareza e desigualdade, temas sobre os que os Wajãpi falavam ao me explicar a ideia de imitação.

\section{FAZER PRECONCEITO}

Durante uma reunião de caxiri, duas cunhadas contaram-me, com evidente desaprovação, sobre os estudantes da cidade que, ao voltaràs aldeias nas férias escolares, faziam preconceito, inveja ou disputa. ${ }^{8}$ Explicaram-me que esses jovens voltam, falam para os outros que eles não têm as coisas, que os pais deles são pobres, que os seus

próprios pais são ricos. Mostram as coisas que compraram na cidade e aprenderam a usar: tablets, celulares, tênis, bonés etc. E quem vive nas aldeias passa a querer esses objetos. No caso daqueles que enviam os filhos ou netos para estudar na capital,

8 | Todos esses termos, disseram-me meus interlocutores, podem ser traduções para o português de jirõarõa. Aproveito para explicitar que a pesquisa foi realizada em língua portuguesa. 
provocam disputa, pois a partir de então, os outros "querem alcançar" e "não querem ser deixados para trás".

Novamente, a lógica do iniciador e imitadores é aparente. Fazer preconceito, compreendi inicialmente, corresponderia a iniciar deliberadamente uma prática ou comprar determinadas coisas e não as compartilhar. Ou a ter algo cujo acesso não é generalizado. Como me disse um interlocutor: "Ele compra roupa, camisa, só para mostrar, invejar". Importante notar que se faz preconceito também em práticas não relacionadas a mercadorias. Se um homem abre uma roça muito grande, os demais quererão também alcançar. Quem fala bem português faz inveja para quem tem menos domínio dessa língua. Também se um caça muito, e outro só caça um jacu, daí fala-se que este é panema, e ele fica invejando. Quando o motivo do preconceito se refere a bens, há modos de se forçar seu compartilhamento: as pessoas pedem coisas aos outros. ${ }^{9} \mathrm{Ou}$, admite a explicação dos Wajãpi, podem chegar a roubá-las, o que enseja estratégias como a construção de casas fechadas ou com cadeados. ${ }^{10}$

No limite, portanto, ser um iniciador pode ser visto como um ato de fazer preconceito, que vai de encontro ao ideal de simetria dos Wajãpi. Como explica Dominique Gallois, a partir das reflexões do falecido chefe Kumai: "O que um tem - uma roça, uma casa, um caminho de caça, etc. - todos devem ter. Com o dinheiro, ocorre o mesmo" (2000: 7). Como discuto adiante, entendo que não se trata de igualdade no sentido de que todos devam possuir as mesmas coisas ou habilidades, mas de simetria. Iniciar uma moda não é necessariamente fazer preconceito, afinal qualquer um pode iniciar uma ação que será potencialmente imitada. A desigualdade malquista pelos Wajãpi, entendo, refere-se a uma assimetria na possibilidade de iniciar modas, a uma fixidez da posição de saliência. Fazer preconceito, assim, parece dizer respeito a uma posição exclusiva ou privilegiada de acesso a novidades. É este argumento que desenvolvo após a discussão bibliográfica que segue.

\section{ASSIMETRIA PELO CONTROLE? ECONOMIAS POLÍTICAS AMERÍNDIAS? OUTRA DISCUSSÃO BIBLIOGRÁFICA}

Quando os Wajãpi diziam que compravam coisas porque tinham visto outra pessoa testando e gostaram, imitando-as, ou quando me contavam das preocupações com os jovens que faziam preconceito e com a possibilidade da desigualdade, estavam falando dos dois modos de circulação de mercadoria que delineei acima? Ou seja, estavam falando de posições de prestígio conquistadas pelo acúmulo e controle assimétrico de bens e a consequente possibilidade de os distribuir, por um lado? Ou, por outro, de relações de compartilhamento, em que a circulação dos bens da sua "forma cozida" (Gordon, 2006b), implicava relações de consaguinização e simetrização? Assim o supus, em trabalhos anteriores (Paula, 2015; 2017). O pressuposto, então, era o de que deter bens seria um ponto necessário à magnificação de pessoas. Esse entendimento
9| Em outro trabalho (Paula 2017) aproximei minhas discussões do conceito de demand sharing, tratado por Peterson $(1993 ; 2013)$ para pensar contextos aborígenes na Austrália. Trata-se de um modo de forçar a generosidade alheia a partir de pedidos explícitos de coisas, e tal modo de forçar o compartilhamento não implica endividamento por parte de quem recebe os bens. Para a América do Sul indígena, Ewart (2013a), Colleoni (2016) e Penfield (2017) utilizam esse conceito para tratar da circulação de bens em suas etnografias.

10|Catherine Gallois (2004) foi quem primeiro notou as "casas de guardar coisas" entre os Wajãpi, cujo objetivo era justamente armazenar itens caros, como combustível ou motores. Já entre os Xikrin do Cateté, Gordon (2006b: 174) especula se as cozinhas não teriam ganhado paredes no fim dos anos 1990 com o intuito de esconder os bens das famílias. Além do roubo e de pedidos, em outros contextos, a feitiçaria pode estar associada a disputas relativas ao não compartilhamento de bens dos brancos (Vanzolini, 2018). 
aproxima-se de autores que pensam em economias políticas ameríndias, ou seja, na ideia de que a política indígena esteja atrelada à produção, controle e circulação de bens (industrializados ou rituais), nomes, relações, força de trabalho (Dal Poz, 2004; Crotti, 2007; Brightman, 2010).

A descrição da figura do chefe como aquele que deve dar coisas e palavras aos seus aldeões é antiga na etnologia da região (Lowie, 1948; Clastres, 2003 [1962]). Como nota Beatriz Perrone-Moisés (2015), discute-se muito quem é superior a quem nessa relação, o chefe ou sua turma. Mas, e se puséssemos em suspensão a metáfora da propriedade (cf. Strathern, 1999) e do controle para pensar as socialidades ameríndias?"1 Escreve Perrone-Moisés:

\footnotetext{
Quem é superior entre um chefe e sua turma? Resolve-se a questão quando a relação é reposta em seu plano, e o que procurávamos num plano político inexistente aparece na chave da festa. Pois a relação entre anfitrião e convidados é assimétrica mas, justamente, é impossível defini-la em termos hierárquicos (Perrone-Moisés, 2015: 55).
}

A antropóloga critica o fato de que todas "as descrições e análises da chefia (não só dos índios, por sinal), costumam arrolar características diferenciais dos chefes no plano que concebemos como 'econômico'. Chefes têm mais roças, mais casas" (2015: 94). No entanto, o que está em questão nas políticas indígenas não é o controle de recursos, mas a distribuição das coisas em festas. A proposta da autora - que seguimos aqui mais nas críticas que estabelece do que nos caminhos de investigação propostos - consiste em deslocar o olhar para a política e a chefia indígenas. Fazem-se coletividades, a partir da ação de chefes, em festas e em guerras. Festa e guerra, assim, são compreendidas por ela como o par relacional-em perpétuo desequilíbrio, como ensinou Lévi-Strauss em A história de lince sobre os dualismos ameríndios - das socialidades no continente. A função-chefe, na visão da autora, consiste assim, em chave de festa, na função-anfitrião - o chefe é aquele que recebe seus convidados, alimenta-os, despende tudo o que possui. É esse o prestígio maior na América indígena.

Outro antropólogo que propõe desvincular a relação entre controle e chefia para pensar as políticas ameríndias é Antonio Guerreiro (2015). Em sua etnografia, argumenta que o chefe kalapalo é o corpo humano perfeito, não porque nasça assim, mas porque mesmo que se façam chefes a partir de chefes - a semelhança implicada na continuidade corporal do critério de filiação é pertinente-, é preciso construir um corpo de chefe e ser reconhecido como tal por outro chefes. Este é ponto central na análise: as relações simétricas entre chefes têm primazia em relação às assimétricas entre o chefe e seu grupo. Nos termos das discussões regionais contemporâneas, sua análise demonstra que ali a filiação adotiva (o chefe como pai de seus aldeões) é caso da afinidade potencial (o chefe com relação a outros chefes).
11 | Controle é uma ideia que aparece em diversos trabalhos sobre a região (Erikson, 1987; Fausto, 2008; Brightman, 2010; Costa, 2013). É bem verdade que esses autores pretendem amerindianizar a noção de propriedade ou controle, buscando entender "como pessoas impingem-se umas às outras" (Fausto, 2008: 343) Amerindianizar conceitos euro-americanos ou partir das descrições ameríndias para operações de tradução que traem a língua de chegada (cf. Viveiros de Castro, 2004) parecem-me procedimentos antropológicos distintos. Creio estarmos diante de dois modos de universalização em antropologia, como discute Viveiros de Castro (2011) 
A função-chefe entre os Kalapalo, ainda de acordo com a análise de Guerreiro, caracteriza-se por algumas ações que têm sido compreendidas na etnologia regional como características das relações de maestria (Fausto, 2008): cuidado e proteção. No entanto, para Guerreiro, o aspecto central na função de chefia é a de esteio: é em torno do chefe que se estabiliza, temporariamente, um grupo. Trata-se de uma relação assimétrica, portanto, mas não de controle. Relações de simetria e assimetria, assim, parecem ser, no caso Kalapalo, inter-relacionadas e alternadas temporalmente. $\mathrm{E}$ transversalmente, diria Tânia Stolze Lima (2005), sobre a assimetria entre os Yudjá.

Em seu trabalho sobre os Yudjá, a relação assimétrica encapsulada na posição iwa é central na teoria etnográfica apresentada sob a forma de livro (Lima, 2005). Para os Yudjá, uma placenta é amiga do bebê, mas este não é amigo dela. Ou seja, trata-se de uma amizade assimétrica, e, de mesmo modo, a relação de amizade entre o chefe e seu pessoal caracteriza-se também pela não reciprocidade da relação. É que o bebê é iwa de sua placenta. Iwa poderia ser traduzido por "dono", mas Lima opta por recusar tal tradução, dados os pressupostos sobre propriedade que, em nossos termos, a palavra carrega. I wa é uma ideia yudjá de relação, é o meio para a criação de unidades sociais.

Sobre a amizade assimétrica, escreve Lima (2005: 90): trata-se da "distribuição diferencial da posição de sujeito, ou [d]a presença de uma função-Eu de caráter eminentemente político". A posição de sujeito, tomada por um iwa, é o que congrega em torno de si um ponto de vista, um grupo. O iwa é, assim, a condição da vida social e, importante notar, é uma posição que circula. O iwa é quem inicia uma ação, vai na frente; é, sobretudo, quem atrai pessoas para uma ação pelo oferecimento de cauim. $\mathrm{Na}$ análise da antropóloga, iwa é antes uma relação do que uma posição ou um personagem. Assim, o chefe (dono de aldeia) ou o capitão (sênior) yudjá são posições articuladas pela relação iwa. Um chefe é quem funda uma aldeia, e essa posição é mais cristalizada do que a ação de convidar para uma cauinagem, mas também é passível de circular.

Se a amizade assimétrica é a forma da relação entre os chefes e os seus, os iwa de dois grupos têm relações de amizade simétrica. Sintetiza Lima (2005: 100): "Em resumo, esta é a configuração do socius que os Yudjá constituem como seu: grupos constituídos internamente por uma assimetria, interligados por uma relação de simetria que, aberta ao evento, pode apresentar estados alternados de assimetria". Por ser circulante, a posição assimétrica da relação iwa não se caracteriza como hierárquica, pois não há a possibilidade de totalização hierárquica. ${ }^{12}$ As próprias noções de igualdade e hierarquia são colocadas em questão como pertinentes para tratar da vida social na Amazônia indígena.

Os trabalhos de Lima (2005) e Guerreiro (2015) tratam da função de chefia como a função de iniciar uma ação, o que acarreta a conformação temporária de um grupo. Com relação à questão dos iniciadores-imitadores wajãpi analisada aqui, eu já notara sua semelhança com outro contexto em que o chefe é aquele que inicia: o caso araweté descrito por Eduardo Viveiros de Castro (1986). Tenetãmõo o chefe araweté, é $\mathbf{1 2}$ | Sobre este ponto, importa reconhecer que os debates sobre hierarquia nas terras baixas da América do Sul são amplos, sobretudo para certos grupos linguísticos (como os Arawak) ou regiões (como o Alto Rio Negro e o Chaco), e não há possibilidade de tratar dessa literatura aqui. Contudo, ressalto que algumas abordagens sobre o tema recusam a ideia de uma totalização hierárquica. Ao buscar compreender as imagens da hierarquia em sistemas regionais como o Alto Rio Negro e o Alto Xingu, Andrello, Guerreiro e Hugh-Jones (2015), por exemplo, argumentam

que ali a hierarquia não se refere a englobamento do contrário (Dumont, 2008): "as hierarquias no Alto Xingu e no Alto Rio Negro parecem fazer uso de uma linguagem temporal e, portanto,

diacrônica" (Andrello, Guerreiro \& Hugh-Jones, 2015: 700, minha tradução). Em um sentido diverso, exploro ao longo do artigo a ideia de uma assimetria wajãpi baseada em um aspecto temporal: é o ato de iniciar uma ação que torna alguém "saliente". 
artigo | Camila Galan de Paula | Assimetria e saliência: a relação entre iniciador/a e imitadores/as na

\begin{abstract}
"o que segue à frente", "o que começa" [...]. O líder Araweté, assim, é o que começa, não o que ordena; o que segue à frente, não o que fica no meio.

Toda e qualquer empresa coletiva Araweté supõe um tenetãmõ: não existe começo inocente, acordo "comum" em que todos estejam na mesma relação com a tarefa. Uma coisa não começa se não houver alguém em particular que a comece. Mas, entre o começar do tenetãmõ, já de si relutante, e o prosseguir dos demais, sempre é posto um intervalo, vago mas essencial: a ação inauguradora é respondida como se fosse um pólo de contágio, não uma abertura legitimadora ou exortativa: e, não obstante, espera-se por ela (Viveiros de
\end{abstract} Castro, 1986: 302-303).

E essa ação de iniciar, não se refere apenas à chefia ou à esfera produtiva.

A aldeia Araweté parecia passar por ciclos, desde no que tocava a modas superficiais (uma canção, uma brincadeira invadiam os dias), até esferas sociológicas (Viveiros de Castro, 1986: 303).

Também na etnografia de Dal Poz (2004), citada anteriormente, percebe-se que a posição de chefia não corresponde apenas ao controle de bens e recursos necessários à generosidade. O chefe Cinta-Larga, zapivaj, é o dono-de-casa. Contudo, há ainda outra figura de liderança naquela sociedade, o bexipo, "o que está à frente", aquele que inicia atividades variadas e é "potencialmente capaz de conjugar e dar forma às atividades grupais. Entre o bexipo e seus companheiros, instala-se um vínculo de cunho funcional, embora de limitada duração" (Dal Poz, 2004: 160). A diferença entre os zapivaj e o bexipo estaria sobretudo no aspecto temporal mais longo da posição do primeiro. Também o dono da casa lidera por ser quem tem iniciativa: de construir uma casa, plantar roça, iniciar festas e guerras (Dal Poz, 2004: 161). As observações dos Cinta-Larga sobre os hábitos do japiim (Cassicus cela) são esclarecedoras, e mostram que a política, para os Cinta-Larga, é menos um domínio que um modo de pensar conformações de coletividades:

\footnotetext{
Pássaro da família dos icterídeos, que nidifica em colônias, coloca-se ao pensamento cinta-larga como uma genuína metáfora para a função zapivaj. Dentre os tipos que foram observados na região amazônica, o japuaçu (Psarocolius bifasciatus) é o maior de todos [...]. Segundo o caçador, o japuaçu escolhia uma árvore e ali pendurava seu ninho; então, seguiam-no os demais tipos, menores e mais numerosos, que daí enchiam a copa da árvore com centenas de ninhos [...]. Justamente por ser o primeiro a construir a morada na árvore escolhida, é que os Cinta-Larga atribuem ao tipo maior uma função homóloga a de dono-de-casa; razão pela qual, para eles, o japuaçu é o irara zapivaj, o chefe dos demais japiins (Dal Poz, 2004: 162-163).
}

Seria possível pensar o iniciador/imitadores Wajãpi a partir desse conjunto de discussões da bibliografia? É o que se busca sugerir a seguir. 


\section{SIMETRIA, DESIGUALDADE, SALIÊNCIA}

Imitação é tema recorrente nas falas dos Wajãpi e, por isso, aparece em trabalhos de outras antropólogas sobre eles, assim como em produções dos próprios pesquisadores indígenas (Pellegrino, 2008; Pesquisadores Wajãpi, 2008; Gallois, 2012; Oliveira, 2012). Como discuti em outra ocasião (Paula, 2017), o que os Wajãpi falavam em português como imitar parece referir-se a ao menos dois processos-mas quando perguntava em língua wajãpi, o termo era sempre o mesmo, wãa ã. Assim, imitar, além de se referir a comprar o que outra pessoa comprou na cidade, ou fazer algo que os outros estão fazendo, também se relaciona a pegar o jeito de alguém, aprender um conjunto de práticas corporais. Rapazes e homens jovens imitavam o corte de cabelo de jogadores de futebol ou de cantores de música sertaneja. Mulheres adultas que começavam a frequentar reuniões e encontros de mulheres indígenas passaram a usar calça jeans e mochila. Imitar esses modos de vestimenta e cabelos, em ambos os casos, não era mera questão de aparência pessoal, mas tratava-se de aprender ou ter aprendido um conjunto de habilidades - saber jogar futebol, cantar música sertaneja ou ser hábil falante do português nas reuniões interétnicas de mulheres.

Imitar, portanto, relaciona-se a atos de aprendizagem (Oliveira, 2012): foi por imitação que os ancestrais dos Wajãpi aprenderam os padrões gráficos que utilizam (Gallois, 2012); assim também aprenderam os cantos e danças das festas com outras gentes nos tempos primordiais (Gallois, 1988). Ou como elucidam os pesquisadores wajãpi (2008: 25), "a gente também imita canoa feita por outro grupo e as casas deles".

A imitação, contudo, é também perigosa e deve ser feita criteriosamente: no caso contemporâneo de replicação de imagens, como fotografias ou filmagens, a imitação replica imagens (ããaga) que carregam o princípio vital (i'ã) do fotografado (Pellegrino, 2008; Pesquisadores Wajãpi, 2008; Gallois, 2012).

Mas não é apenas no caso de imagens que a imitação é perigosa:

A imitação feita desmedidamente pode acarretar na transformação em outro, tal como ocorreu com alguns taivigwerã em tempos passados. Primeiro foram dois irmãos que, ao brincarem (ojimarai) de macaco-aranha, enegreceram seus corpos com jenipapo e avermelharam seus rostos com urucum; subiram, então, em uma árvore e, imitando (owa'ã) os gritos e movimentos do primata, transformaram-se em macaco-aranha, sumindo mata à dentro. Posteriormente, outro taivïgwerã pintou-se como guariba (o corpo de vermelho e a face de preto) e ao trepar nas árvores, metamorfoseou-se. Por fim, um antepassado juntou frutos de pequi, ateou fogo e com as cinzas gordurosas desenhou manchas de jaguar pelo corpo; com o intuito de assustar um cunhado, enrolou sua kamisa pirã como um rabo e pôs-se de quatro a imitar, dizendo-Ihe: "Emãe tairo, jawarã ije" ["Veja cunhado, onça eu sou"]. E assim se transformou por completo (Oliveira, 2012: 86, inserção da autora). 
A imitação excessiva do corpo e modo de outros, assim, pode levar a uma indesejada transformação. Semelhantemente, não se deve ornamentar exclusivamente com motivos gráficos de um só tipo, vindos de um só animal. Joana Cabral de Oliveira, em seguida a esses fragmentos de narrativas, sugere que wã'ã seja "um modo de reviver uma experiência" (2012: 186). Talvez seja, sugeri, um modo de experimentar temporariamente outro corpo-perspectiva (Paula, 2017).

Dessa discussão importa notar que imitar, para os Wajãpi, é tanto ato fundamental de aprendizagem quanto é perigoso; não se deseja ser idêntico ao outro ao efetuar a imitação. Assim, quando os Wajãpi me explicavam que não pode ter desigualdade, entendo que não estavam reivindicando a indistinção como ideal, mas certo senso de simetria. Mais precisamente, como desenvolvo adiante, a simetria da possibilidade da posição de iniciador. Isso porque meus interlocutores falavam-se sobre quem comprou primeiro determinada coisa, e não tanto sobre quem comprava muitos itens. ${ }^{13}$ Importa ser o primeiro a comprar algo, ou a inaugurar uma moda -é o destaque conferido por esse tipo de ação que proponho chamar de saliência. O iniciador, portanto, ocupa uma posição assimétrica com relação aos imitadores não porque detém acesso a muitos bens, e menos ainda a bens exclusivos, mas porque é, justamente, alguém que teve uma iniciativa de compra. Tal posição assimétrica, assim, parece referir-se a uma qualidade de distinção ou saliência, e não (ou não exclusivamente) de controle desigual a mercadorias. No caso de coisas com uso muito espraiado em toda a TI, não se sabe ao certo o iniciador. Já no caso de objetos como celulares, tablets, carro, máquina de lavar roupa (que fica no aluguel de Macapá, não na TI, onde as aldeias não possuem energia elétrica) todos sabem quem comprou primeiro. Quando outros passam a comprar, o efeito de saliência parece diminuir. Presilhas para cabelo de modelos inovadores, panelas diferentes, tudo isso parece interessare ser alvo de imitação, mesmo que por curto período.

O risco da desigualdade, dessa feita, não se relacionaria a alguém poder comprar e fazer circular mais do que os demais. A desigualdade implica que algumas poucas pessoas passariam a ser sempre as iniciadoras de modas, ocupando a posição de saliência de modo perene. A ideia de desigualdade implicada em afirmações como não pode ter desigualdade, assim, talvez se refira ao incômodo de os estudantes da cidade e os assalariados se tornarem os únicos com acesso a novidades, os únicos capazes de inaugurar ações - iniciar o uso de certa peça de roupa, mas também de cortes de cabelo, de conhecimentos musicais, políticos, linguísticos, dentre outros saberes e objetos acessados fora da Terra Indígena. O receio é que essas pessoas se tornem os únicos centros de catalização dos processos da vida social (Lima, 2005: 113), ao menos no que diz respeito ao âmbito das mercadorias. O ideal de simetria ou igualdade dos Wajãpi - "não pode ter desigualdade" -, portanto, talvez seja antes de tudo uma contrahierarquia, como sugere Lima (2005: 113) sobre os Yudjá.

Em suma, o risco apontado pelos Wajãpi é o de que haja a cristalização de uma posição de iniciador. O receio é o do congelamento do movimento impresso pela
13 É preciso reconhecer contudo, que nem todas as famílias possuem possibilidades de compras equânimes, uma vez que nem sempre há assalariados (professores, agentes indígenas de saúde, agentes de saneamento básico, merendeiras) ou aposentados entre seus membros. Não estudei a distribuição de assalariados entre as famílias ou, mais propriamente, como se organizam grupos familiares em torno dos assalariados. Tinoco (2000) analisa a influência que alguns chefes tiveram em fazer seus filhos $\mathrm{e}$ netos serem escolhidos para ser formados professores e, futuramente, receber salários.

Sua análise, no entanto, não pensa a chefia como um processo ou uma ação política, como a bibliografia mais recente vem fazendo (cf. Sztutman, 2005). Dessa feita, não é possível compreender como o contexto de disputas por posições assalariadas pode ter sido importante na confirmação de chefes e nas relações entres os grupos locais (wana kõ) wajãpi. 
dinâmica do iniciador-seguidores, em que a possibilidade de iniciar um ato está sempre potencialmente aberta. No mundo wajãpi, a estabilidade da posição de saliência é sempre momentânea; uma aldeia dura mais do que a moda de cortes de cabelo, mas os genros de um chefe de aldeia muito provavelmente tentarão eles próprios ser fundadores de suas aldeias. ${ }^{14}$

Sugiro, assim, que a ação política wajãpi opera pela ação de se tornar saliente. Pensar em termos de saliência, ao invés de magnificação, tem a meu ver a vantagem de não imaginar a priori a diferença implicada na ação política como eivada pelo controle, tal anos após o casamento. como fazem algumas leituras de donos/mestres como pessoas magnificadas, em especial o foco na relação de maestria como relação entre continente e conteúdo (Fausto, 2008). Isso não significa abandonar a possibilidade de assimetrias nos mundos ameríndios, apenas torna crucial "se perguntar quais as formas indígenas da assimetria, e como elas diferem das nossas ideias 'nativas' ou conceitos antropológicos sobre a questão." (Guerreiro, 2018: 54). A pergunta de Guerreiro, inclusive, ecoa a sugestão de Fausto:

\footnotetext{
Há que se construir uma nova linguagem, etnograficamente informada, para conceitualizar as relações assimétricas na região sem, de um lado, dissolvê-las em um banho simetrizador ou, de outro, transformá-las em sementes contendo um aparelho estatal em miniatura (2008: 342).
}

A questão que se coloca, assim, é a de como encarar as relações da assimetria e da política nos mundos ameríndios. Magnificação via apropriação, controle e cuidados de outras criaturas? Ou saliência instaurada pelo ato de iniciar uma ação? Pessoa plural do mestre (Fausto, 2008) ou centro circulante de catalização de ação social (Lima, 2005)? A questão é demasiado ampla e eu não tenho condições de respondê-la plenamente. De todo modo, para os fins deste artigo, é possível olhar para os "donos" no mundo wajãpi para tentar situar a questão e indicar uma resposta.

Fausto (2008) ao escrever sobre a figura dos "donos" na Amazônia, argumenta que não se trata de esquadrinhar um domínio ontológico; as relações de maestria conformam um esquema relacional ameríndio. De todo modo, vejamos como a literatura sobre os Wajãpi descreve o que traduz por "donos" (-jarã). Gallois (1988: 98) define a relação entre donos (-jarã) e suas criaturas (eima) ou seguidores (emĩwãe) como uma relação de posse, de controle e de cuidado, pois o dono controla a reprodução, crescimento e bem-estar de suas criaturas.

A noção de -jarã wajãpi é múltipla: "reúne ao mesmo tempo, a ideia de indivíduo primordial na especiação, de pai ou mestre responsável pela espécie, e ainda de líder" (Gallois, 1988: 165). O controle das criaturas por seu dono é feito pelo tupasã, caminho visível apenas por quem tem pajé, isso é, por quem tem substância xamânica em seu corpo. É por esses fios tupasã que o dono das queixadas as controla, lidera, e delas cuida. Puxando os fios presos em seu pulso "ele anda na frente, os porcos andam atrás dele" 
(: 112), e assim os lidera ao curral, onde cuida deles. Este dono, assim, controla e cuida de suas criaturas, mas também as lidera, indo à frente de seu pessoal. O sol, a chuva, e o vento são controlados por Monpera, guardião da porta do céu, que os mantém na borda do céu (: 66). Mas esses seres também possuem donos terrestres: certo tipo de cigarra é kwara'yjarã, dona do sol/verão, uma vez que ela é o primeiro ser a chegar na estação seca, sendo seguidas por outros seres. De modo similar, a rã moruwa é dona da chuva: são esses seres que anunciam a chegada das águas:

[...] chegam do final da terra em suas canoas; algumas semanas antes, eles são anunciados pelo barulho das árvores derrubadas pelo vento, quando estão preparando suas embarcações. Permanecem por três meses, cantando sozinhos; a chegada de iui (rã,

Hilídeos) que acompanham morua por alguns dias, anuncia a estiagem (Gallois, 1988: 66).

Assim, a ideia de "donos" entre os Wajãpi indica relação de cuidado e controle, mas também de liderança e início de ação.

Talvez entre as relações de saliência - cujo fundamento principal é o destaque adquirido pelo ato de iniciar uma ação - e as relações de maestria haja uma diferença de grau e não de natureza. ${ }^{15}$ De todo modo, a opção deste artigo foi enfatizar as relações que proponho chamar de "saliência". A meu ver, elas oferecem chave renovada de leitura para entender a circulação de bens industrializados entre povos indígenas. Ainda, no caso específico de minha pesquisa, permite a aproximação entre o tema dos bens industrializados e outras etnografias sobre os Wajãpi.

Ainda sobre os donos, Gallois indica que de um modo geral "a relação entre donos de espécies naturais e suas criaturas não é propriamente associada à 'chefia' [...], embora o mestre de uma espécie possa ser qualificado, em alguns casos, por este qualificativo" (1988: 98-99). Um ser chamado de chefe (rovijã) será "um indivíduo específico, cujo tamanho monstruoso denota a posição de primazia, ou de paternidade da espécie" (:165). É o caso da sumaúma, tratada por alguns dos interlocutores de Dominique Gallois por chefe dos donos das árvores (ywyrajarã rovijã) (:117). Também Joana Cabral de Oliveira (2012: 62-68) mostra em sua etnografia que árvores grandes, como sumaúmas ou angelins, podem ser ditas chefes de árvores. ${ }^{16}$ Em outro artigo, a mesma antropóloga (Oliveira, 2015) sugere que a lógica do sensível (cf. Lévi-Strauss, 2010), entre os Wajãpi, perpassa as perspectivas. Ou seja, se as coisas do mundo mudam de acordo com o ponto de vista, as características sensórias cruzam perspectivas. De acordo com a autora, é pela "grandeza descomunal" de certas árvores que elas são designadas chefes, rovijã. O "tamanho grande e a proeminência (destaque) que alguns indivíduos assumem em relação aos demais do mesmo grupo" (Oliveira, 2012: 63) é o que faz certos espécimes serem chamado chefe. ${ }^{17}$

Dessa forma, na fala de um interlocutor de Oliveira (2012: 65), o angelim, (peyryry) foi designado como chefe, peyryryrovijãa, tendo inclusive seguidores (-emĩwãe). Assim
15 | Agradeço a um/a dos/as pareceristas por essa sugestão. Seria necessária a realização de uma pesquisa orientada especificamente sobre este tema para tornar a sugestão em hipótese de pesquisa e verificar sua pertinência para o contexto wajãpi. No entanto, a literatura sobre o domínio dos donos entre os Wajãpi parece efetivamente apresentar casos que, em minha leitura, dizem respeito a ambos os tipos de relação.

16 | Já Gallois aponta que alguns dos diversos donos da floresta (ka'ajarã) podem ser por vezes "referidos pelo nome de uma série de árvores particularmente importantes nos ritos xamanísticos" (1988: 117) como sumaúma e angelim. Essas árvores podem ser "donos", assim, porque possuem tupasã, os fios xamânicos que ligam um pajé a suas criaturas.

17| Neste ponto, importa notar que Oliveira (2012: 67) já discutiu com proposições das ciências cognitivas para argumentar que é possível que as árvores chefes sejam protótipos cognitivos de categorias. Segundo Oliveira contudo, as abordagens cognitivas não perguntam pelo modo como os protótipos são eleitos, e argumenta que a "dimensão sensível é algo determinante nesse processo. As árvores ou pássaros chefes são escolhidos por se destacarem dos demais por algumas dimensões sensiveis extremas, tais como: o enorme tamanho do angelim, do patauá e do gavião real" (2012: 67). Talvez fosse o caso de indagar se essas árvores "chefes" não poderiam ser entendidas como "exemplos salientes" (salient examples) de uma categoria (Lakoff, 1990: 89-90), um dos modelos metonímicos com efeitos de protótipos para a teoria de categorização proposta por Lakoff. Segundo esse autor, "It is common for people to use a familiar, memorable, or otherwise salient examples to comprehend categories" (1990: 89). A crítica que Oliveira estabelece às abordagens cognitivas da classificação pode ser inclusa no tipo de crítica que antropólogos socioculturais fazem à antropologia cognitiva: "[..] that formal analysis could never provide overarching cultural descriptions of individual societies of the types expected in information-rich ethnographies. Formal analysis 
como não há um só chefe entre os Wajãpi, admite-se muitos chefes-árvores. Na mesma conversa com a antropóloga em que angelim foi dito rovijã, em seguida também waa, um tipo de abiu selvagem, foi considerado chefe - de outras árvores frutíferas; chefe dos seus, portanto. Nesses casos, é o grande porte e a saliência de alguns seres que os torna chefes - não exatamente de uma espécie, nos termos da nossa biologia, mas de um conjunto de seres considerados semelhantes.

Além de ser proeminente, o chefe vegetal também alegra sua turma. É o que disse uma mulher a Oliveira (2012: 68), sobre a relação entre as mandiocas e outro tubérculo, makwari, que seria o "temi'õ rovijã", o chefe da plantação das mandiocas: "Porque você planta mandioca junto dele [makwari] e então a plantação de mandioca vai ficar alegre". Também o angelim, chefe de várias árvores, "deixa os outros bem, ele deixa os outros alegres", fortalecendo-os. O chefe, assim, é proeminente, alegra, fortalece. Um chefe wajãpi, de acordo com Tinoco (2000: 54), é justamente aquele que promove o "entendimento e cooperação entre indivíduos e grupos locais", que provê para os seus, é bom orador, é generoso. É ainda fundador de aldeia e exerce continuamente a capacidade de manter seus genros juntos de si; inicia e mantém, portanto, um agrupamento de pessoas a partir de um ato fundacional - e assim reencontramos a discussão dos chefes ameríndios como iniciadores e conformadores de grupos (Viveiros de Castro, 1986; Lima, 2005; Guerreiro, 2015). Além disso, o "chefe é aquele que tem mais experiência, tem mais conhecimento, é sabido" (Pesquisadores Wajãpi, 2009: 12).

A partir do que escreve Oliveira sobre as árvores consideradas rovijã, das características da chefia wajãpi e da bibliografia sobre política ameríndia, é possível especular se além de provedoras e salientes, as árvores-chefe não são também iniciadoras de agrupamentos. Pensemos no angelim, que Oliveira (2012: 67) trata como "um chefe generalizado (tovijã kõ) das árvores". Aprende-se em uma publicação do Instituto Nacional de Pesquisas da Amazônia (INPA) que o angelim-vermelho (Dinizia excelsa Ducke), considerando suas relações ecológicas, é tido como espécie pioneira, na classificação dual de Swaine \& Withmore (1998) ou como oportunista, em classificações ternárias. A divisão de espécies de árvores em grupos ecológicos divisão em disputa, cujos critérios e características não são unívocos - entre pioneiras e não pioneiras (ou clímax), ou entre pioneiras, oportunistas e clímax referem-se à ordem de sucessão das árvores após a "fase de clareira (gap-phase)" em ciclos que compreendem as fases "clareira, construção e madura (gap, building and mature)" (Swaine \& Withmore, 1998: 81). Espécies pioneiras, para Swaine e Withmore (1998: 82) são "species whose seeds can only germinate in gaps in the forest canopy open to the sky and in which full sunlight impinges at ground level for at least part of the day", e as climax são as espécies cujas sementes germinam à sombra. Uma árvore pioneira, de acordo com esses autores, não pode ser entendida apenas como a "pioneira" no sentido de sensocomum do termo, tendo uma série de características que em geral compartilham. De was perceived by critics as too narrow and piecemeal for holistic ethnographic descriptions" (Blount, 2011: 15), ao que os antropólogos cognitivos responderiam que "their method of representing informant knowledge was more principled and thus more accurate, in contrast to impressionistic, non-replicable ethnography." (: 15). Como indicado na nota 4, não formulei a questão e o desenvolvimento deste artigo em consonância a questões da antropologia cognitiva, o que demandaria questões e dados formulados de outro modo - inclusive alguns autores localizam a antropologia cognitiva não como parte da antropologia sociocultural, mas da "antropologia científica" (Blount, 2011) ou das ciências cognitivas (Brown, 2006; Boster, 2012). Apenas indico aqui uma discussão em que a "saliência" poderia encaminhar para outras questões desde que a pesquisa fosse inteiramente reformulada. 
todo modo, o fato é que há árvores que só se desenvolvem "até o dossel quando ocorre uma abertura natural (clareira) pela queda ou morte de outras árvores" (Mesquita, Ferraz \& Camargo, 2009), e é caso do angelim, que, no entanto, é caracterizado por Ferraz et al. (2004) como atípica no conjunto das características comumente associadas à classificação de sucessão florestal.

A partir dessa digressão sobre sucessão florestal, indago se o angelim e outras árvores ditas chefes (rovijã) não são também as que iniciam uma fase de um ciclo ecológico, sendo seguidas por árvores que crescem à sua sombra. Árvores iniciadoras e árvores que morrem, podendo a posição de iniciador-chefe circular. Antes dos machados de ferro, era na clareira de angelins queimados que os Wajãpi abriam suas roças (Oliveira, 2020: 7). E uma aldeia sempre nasce de uma roça (: 8), embora nem toda roça origine uma aldeia. No caso de chefes de aldeias que conseguem manter muitos de seus genros (ou até mesmo filhos) juntos de si, é comum perceber as tentativas dos mais jovens de iniciar suas próprias aldeias a partir das roças. Às vezes constroem ali uma casa, vivem temporariamente na nova roça-aldeia. Podem chamar o local de "aldeia", enquanto seu sogro chama-o de "roça". De todo modo, começar uma aldeia implica antes abrir uma roça. E, conforme explica Oliveira, roças eram abertas na clareira de um angelim queimado. Um chefe-árvore que é sucedido por um chefe-humano? É possível imaginar que sim. O imponente angelim ocupa uma posição de saliência por muito tempo antes de ser queimado e sucedido por uma roça, que pode vir a ser a aldeia de seu fundador humano. ${ }^{18} \mathrm{Afinal}$, "o que era roça volta a ser floresta. O que era floresta, volta a ser roça” (Oliveira, 2020: 9).

A criação primeva da floresta se deu quando sumaúma, por ação do criador, brotou e foi seguida pela figueira (Oliveira, 2020). ${ }^{19}$ Sufocada pela figueira, a sumaúma morreu e suas folhas secas espalhadas pelo vento originaram toda a floresta. As árvores primeiras, e a morte de árvores, assim, são alvo de reflexão do pensamento wajãpi.

Neste ponto, é preciso admitir que minha sugestão de pensar a ação do iniciador do uso de certos bens industrializados como uma ação de fazer-se saliente não abarca todo o domínio das ações diferenciadoras relativas a posições de chefia. Ser o iniciador no uso de um determinado tipo de jaqueta não conforma um grupo, uma turma, um pessoal - ao menos não no modo como comumente pensamos. Ao iniciador de uma moda, além disso, também falta toda a sorte de características bem-quistas num chefe: a oratória, o apaziguamento, a capacidade de agrupar, alegrar e fortalecer seus aldeões. No entanto, imagino ser possível ao menos levantarmos a hipótese de que iniciar uma ação relacione-se a processos sempre temporários de conformação de agrupamentos que implicam numa saliência daquele que começa a ação. Pois "só há incansável e insistente começar uma vez mais" (Oliveira, 2020: 11), o que vale para a floresta, que vira roça, que vira capoeira, e novamente floresta. E para as posições de saliência, que são ocupadas de modo sempre provisório, a partir de um novo ato de começar. Se e de que modo essa saliência se alia a outros atributos, é o caso de se

18 | Mas não se trata de mera substituição de um espaço de floresta por um espaço vivido entre humanos: antes da fundação de uma nova aldeia, os donos wajãpi das roças precisam primeiro ter afastado "os ciumentos -jarã da terra, das árvores, dos animais e da floresta" (Oliveira 2020: 8), e com a plantação dos cultivares das roças, chegam junto os donos das mandiocas, das batatas, etc.

19| Em sua tese, Oliveira (2012: 10-11) fala em sumaúma e fícus, e não figueira. 
verificar empiricamente. Penso, em suma, que é porque o ato de iniciar entre os Wajãpi é central que eles refletem em termos de imitação de alguém que começa uma ação para explicar as "modas" relativas aos bens comprados na cidade.

\section{CONCLUSÃO}

Talvez o trabalho de compreender e traduzir mundos seja sempre inconcluso. Este, restrito e especulativo, certamente o é. A partir de questionamentos suscitados pelo diálogo com outra bibliografia, realizei o exercício de duvidar das categorias e discussões que empregara para compreender o que me disseram os Wajãpi sobre imitação.

Alguém compra algo, podendo ou não fazer preconceito. Outras pessoas, assim, imitam e compram coisas semelhantes. Outros, sem acesso a dinheiro ou à cidade (sem ser assalariados), não conseguem imitar, quanto menos tornar-se iniciadores. Está aberta a possibilidade da indesejada desigualdade. Numa pesquisa breve e feita em português, ainda que buscando me aproximar das explicações e sentidos dados pelos Wajãpi a imitar, preconceito, desigualdade, difícil não se enganar sobre o que poderiam ser interessantes equivocações (cf. Viveiros de Castro, 2004). Como deslocar metáforas (cf. Strathern, 2006) e compreender acepções de imitar, preconceito, desigualdade que não estejam ancoradas em pressupostos da propriedade, do controle, da hierarquia, da produção?

Este artigo, assim, é antes de tudo um convite a outro modo de pensar a circulação de bens industrializados entre povos ameríndios das terras baixas sul-americanas. Trata-se de propor a reflexão sobre o tema a partir das imagens mobilizadas pelos interlocutores em campo. Quais as relações políticas implicadas nos usos desses bens e, sobretudo, como tais relações são expressas? Se imaginarmos uma antropologia cuja tarefa seja a de traduzir mundos (Viveiros de Castro, 2004), ampliando os próprios conceitos da teoria social, então os modos wajãpi de pensar as disputas em torno de quem compra bens primeiro podem ser válidos para pensar política sem que precisemos pensar em economias políticas ameríndias, em hierarquia, em controle.

\section{AGRADECIMENTOS}

Agradeço a Marina Vanzolini e Karen Shiratori, pois foi numa disciplina ministrada por elas no PPGAS da USP que revi meu material de pesquisa à luz das discussões deste artigo. Agradeço também a Karen, bem como a Rodrigo Brusco, pelas leituras e comentários a diferentes versões deste artigo. Obrigada ainda a Rodrigo Lazaresko Madrid pelas conversas sobre ciências cognitivas, que me ajudaram a responder questões das/os pareceristas anônimas/os. Às/aos pareceristas igualmente agradeço pelas sugestões e objeções. A todas as pessoas 
na T.I Wajãpi que me receberam em suas casas, aldeias e escolas entre 2013 e 2017, como pesquisadora e assessora.

Camila Galan de Paula é professora assistente no Colegiado de Antropologia da Universidade Federal do Vale do São Francisco (UNIVASF), campus Serra da Capivara (São Raimundo Nonato-PI). Mestra e doutoranda em Antropologia Social pelo Programa de Pós-Graduação em Antropologia Social da Universidade de São Paulo. Bacharel e licenciada em Ciências Sociais também pela USP. Integra os seguintes grupos de pesquisa: Hybris - Crupo de estudo e pesquisa sobre Relações de Poder, Conflitos, Socialidades e o Laboratório de metodologia, pesquisa e documentação em Antropologia (LaMPDa).

CONTRIBUIÇÃO DE AUTORIA: Não se aplica

FINANCIAMENTO: Este artigo é resultado de reflexões posteriores relativas a uma pesquisa de mestrado financiada com uma bolsa da Fundação de Amparo à Pesquisa do Estado de São Paulo (FAPESP), Processo No. 12/23868-3.

\section{REFERÊNCIAS BIBLIOGRÁFICAS}

ANDRELLO, Geraldo; GUERREIRO,

Antonio; HUGH-JONES, Stephen. 2015.

Space-Time Transformations in the Upper Xingu and Upper Rio Negro. Sociologia \& Antropologia, v. 5 n. 3: 699-724. DOI: https:// doi.org/10.1590/2238-38752015v533

BLOUNT, Ben C. 2011. "A History of Cognitive Anthropology". In: KRONENFELD, David; BENNARDO, Giovanni; MUNCK, Victor C. de; FISCHER, Michael D. (org.). A Companion to Cognitive Anthropology. Malden, MA, Wiley-Blackwell, pp. 11-29.

BOSTER, James S. 2012. Cognitive anthropology is a cognitive science. Topics in Cognitive Science, v. 4 n. 3: 372-378. DOI: https://doi. org/10.1111/j.1756-8765.2012.01204.x
BOYER, Pascal. 2000. Functional Origins of Religious Concepts: Ontological and Strategic Selection in Evolved Minds. The Journal of the Royal Anthropological Institute, v. 6, n. 2: 195-214. DOI: https://doi.org/10.1111/1467-9655.00012

BRIGHTMAN, Marc. 2010. Creativity and Control: Property in Cuianese Amazonia. Journal de La Société des Américanistes, v. 96, n. 1 : 135-167. DOI : https://doi.org/10.4000/jsa.11303

BROWN, Penelope. 2006. "Cognitive Anthropology”. In: JOURDAN, Christine.; TUITE, Kevin. (org.). Language, culture, and society: key topics in linguistic anthropology. Cambridge and New York, Cambridge University Press, pp. 96-114. 
CLASTRES, Pierre. [1962] 2003. "Troca e poder: filosofia da chefia indígena”. In: CLASTRES, Pierre. A sociedade contra 0 Estado: pesquisas de antropologia política. São Paulo, Cosac Naify, pp. 45-63.

COLLEONI, Paola. 2016. Becoming Tamed. The Meaning of 'Becoming Civilized' among the Waorani of Amazonian Ecuador. Tipiti: Journal of the Society for the Anthropology of Lowland South America, v. 14, n. 1: 72-101. http://digitalcommons. trinity.edu/tipiti/vol14/iss $1 / 5$

COSTA, Luiz. 2013.Alimentação e comensalidade entre os Kanamari da Amazônia Ocidental. Mana-Estudos de Antropologia Social, v. 19, n. 3: 473504. DOI: http://dx.doi.org/10.1590/ S0104-93132013000300003

DAL POZ, João. 2004. Dádivas e dívidas na Amazônia: parentesco, economia e ritual nos Cinta-Larga. Campinas, tese de doutorado, Universidade Estadual de Campinas.

DUMONT, Louis. [1966] 2008. Homo Hierarchicus: O Sistema de Castas e Suas Implicações. 2 ed. São Paulo, EDUSP, 2008.

ERIKSON, Philippe. 1987. De l'apprivoisement à l'approvisionnement: chasse, alliance et familiarisation en Amazonie amériendienne Techniques \& Culture, v. 9: 105-140. DOI: https://doi.org/10.4000/tc. 867

EWART, Elizabeth. 2013a. Demanding, Giving, Sharing, and Keeping: Panará Ideas of Economy. The Journal of Latin American and Caribbean Anthropology, v. 18, n. 1: 31-50. DOI: https://doi.org/10.1111/jlca.12002

EWART, Elizabeth. 2013b. Space and society in central Brazil: a Panará ethnography. London and New York, Bloomsbury Academic.

FAUSTO, Carlos. 2008. Donos demais: maestria e domínio na Amazônia.
Mana-Estudos de Antropologia Social, v. 14, n. 2: 329-366. DOI: https://doi. org/10.1590/S0104-93132008000200003

FERRAZ, Isolde D. K.; LEAL FILHO, Niwton; IMAKAWA, Angela Maria; VARELA, Vania Palmeira; PIÑA-RODRIGUES, Fátima. 2004. "Características básicas para um agrupamento ecológico preliminar de espécies madeireiras da floresta de terra firme da Amazônia Central". Acta Amazonica, v. 34, n. 4: 621-633. DOI: https://doi. org/10.1590/So044-59672004000400014

CALLOIS, Catherine ]. S. 2004. Sentidose formas do habitar indígena: entre mobilidade e sedentarização. Estudo de caso entre os Wajãpi do Amapá. Rio de Janeiro, dissertação de mestrado, Universidade Federal do Rio de Janeiro.

GALLOIS, Dominique. 1988. O Movimento na Cosmologia Waiãpi: criação, expansãoe transformação do universo. São Paulo, tese de doutorado, Universidade de São Paulo.

GALLOIS, Dominique. 1992. "Arte iconográfica Waiãpi". In: VIDAL, Lux (org.). Grafismo indígena: estudos de antropologia estética. São Paulo, Studio Nobel; Edusp; Fapesp, pp. 209-230.

GALLOIS, Dominique. 2000. Situação atual dos Waiãpi no Amapá e viabilidade de execução de Projeto "Recuperação do ambiental e despoluição de áreas degradadas por garimpo na TI Waiãpi". Relatório PD/A. (Documento não publicado).

CALLOIS, Dominique. 2002. "Vigilância e controle territorial entre os Wajãpi: os desafios para superar uma transição na gestão do coletivo". In: GRAMKOW, Márcia M. (org.). Demarcando Terras Indígenas II. Experiências e desafios de um projeto de parceria. Brasília, FUNAI; PPTAL; GTZ, pp. 95-112.

GALLOIS, Dominique. 2012. Donos, detentores e usuários da arte gráfica kusiwa. Revista de Antropologia, v. 55, n. 1:19-49. DOI: https:// doi.org/10.11606/2179-0892.ra.2012.46956 
CELL, Alfred. 1998. "Style and Culture". In: CELL, Alfred. Art and Agency: An Anthropological Theory. Oxford and New York, Oxford University Press, pp. 155-220.

GILLIN, John. 1948. "Tribes of the Guianas". In: STEWARD, Julian. H (org.). Handbook of South American Indians: Volume 3. The Tropical Forest Tribes. Washington, Bureau of American Ethnology Bulletin, pp. 799-860.

CORDON, Cesar. 2006a. "Chefes ricos e comunidade pobre: a quantificação monetária do prestígio entre os XikrinMebengokre (Kayapó)". Anais do $30^{\circ}$ Encontro Anual da ANPOCS, Caxambu.

CORDON, Cesar 2006b. Economia selvagem: Ritual e mercadoria entre os índios Xikrin-Mebêngôkre. São Paulo e Rio de Janeiro, Ed. da UNESP; ISA; NUTI.

GRAEBER, David. 2011. Consumption. Current Anthropology, v. 52, n. 4: 489-511. DOI: https://doi.org/10.1086/660166

CROTTI, Vanessa. 2007. Nurturing the Other: Wellbeing, Social Body \& Transformability in Northeastern Amazonia. Cambridge, tese de doutorado, University of Cambridge.

CROTTI, Vanessa. 2013. The Wealth of the Body: Trade Relations, Objects, and Personhood in Northeastern Amazonia. The Journal of Latin American and Caribbean Anthropology, v. 18, n.1: 14-30. DOI: https://doi.org/10.1111/jlca.12001

GUERREIRO, Antonio. 2015. "Fazendo substitutos: A questão da hereditariedade"; "O encontro com a onça". In: CUERREIRO, Antonio. Ancestrais e suas sombras: uma etnografia da chefia Kalapalo e seu, ritual mortuário. Campinas, Ed. da Unicamp, pp. 129-182; pp. 183-250.

GUERREIRO, Antonio. 2018. Chefia e política na América do Sul indígena: um balanço bibliográfico para além do modelo clastreano. Revista Brasileira de Informação Bibliográfica em Ciências Sociais-Bib. 87: 41-70. DOI: https://doi.org/10.17666/bib8703/2018

HOWARD, Catherine. V. 2002. "A domesticação das mercadorias: Estratégias Waiwai". In: ALBERT, Bruce e RAMOS, Alcida. (org.). Pacificando o branco: cosmologias do contato no Norte-Amazônico. São Paulo, Ed. da UNESP; Imprensa Oficial; IRD, pp. 25-55.

HUCH-JONES, Stephen. 1992. "Yesterday's luxuries, tomorrow's necessities: business and barter in northwest Amazonia". In: HUMPHREY, Caroline; HUCH-JONES, Stephen (Org). Barter, exchange and value: an anthropological approach. Cambridge, Cambridge University Press, pp. 42-74.

LAKOFF, Georg. 1990. Women, Fire, and Dangerous Things: What Categories Reveal about the Mind. Chicago and London, The University of Chicago Press.

LÉVI-STRAUSS, Claude. [1962] 2010. La pensée sauvage. Paris, Plon.

LIMA, Tânia Stolze. 2005. Um peixe olhou para mim: o povo Yudjá e a perspectiva. São Paulo e Rio de Janeiro, Ed da UNESP; ISA; NuTI.

LOWIE, Robert. H. 1948. Some Aspects of Political Organization Among the American Aborigines. The Journal of The Royal Anthropological Institute of Creat Britain And Ireland, v. 78, n. 1/2: 11-24. DOI: https://doi.org/10.2307/2844522

MESQUITA, Mariana; FERRAZ, Isolde D. K; CAMARCO, José L. C. 2009. "Angelimvermelho, Dinizia excelsa Ducke". In: MESQUITA, Mariana; FERRAZ, Isolde; D. K.; CAMARCO, José L. C. (org.). Manual de Sementes da Amazônia. Manaus, INPA, Fascículo 8.

NOVO, Marina Pereira. 2017. "Esseé meu patikula": Uma etnografia do dinheiro e outras coisas entre os Kalapalo de Aiha. 
São Carlos, tese de doutorado,

Universidade Federal de São Carlos.

OLIVEIRA, Joana Cabral de. 2012. Entre

Plantas e Palauras: Modos de Construção

de Saberes entre os Wajãpi (AP). São

Paulo, tese de doutorado, Universidade

de São Paulo. DOI: https://doi.

org/10.11606/T.8.2012.tde-22082012-100255

OLIVEIRA, Joana Cabral de. 2015. "Ensaio sobre práticas cosmopolíticas entre famílias Wajãpi sobre a imaginação, o sensível, o xamanismo e outras obviedades". Mana-Estudos de Antropologia Social, v. 21, n. 2: 297-322. DOI: https://doi. org/10.159o/0104-93132015V21n2p297

OLIVEIRA, Joana Cabral de. 2020. (R)(E) Feito Floresta. ClimaCom - Florestas,v. 7, n. 17: 1-14. http://climacom.mudancasclimaticas. net.br/joana-de-oliveira-florestas/

PAULA, Camila Galan de. 2014. Populações indígenas e mercadorias: reflexões a partir da antropologia social. In: USP Ensina Sociologia. (Material instrucional online). http://ensinosociologia.fflch. usp.br/sites/ensinosociologia.fflch. usp.br/files/Camila_texto.pdf

PAULA, Camila Galan de. 2015. Num mundo de muitos corpos: um estudo sobre objetos e vestimentas entre os Wajãpi no Amapá. São Paulo, dissertação de mestrado, Universidade de São Paulo. DOI: https://doi. org/10.11606/D.8.2016.tde-11032016-140934

PAULA, Camila Galan de. 2016. Roupas que combinam e uma discussão sobre calças: Fabricação de corpos wajãpi. Ponto.Urbe, v. 19. DOI: https:// doi.org/10.4000/pontourbe.3187

PAULA, Camila Galan de. 2017. Imitação e fazer preconceito: circulação de objetos, roupas, modas e jeitos entre os Wajãpi
(Amapá). Espaço Ameríndio, v. 11, n. 1: 64-92. DOI: https://doi.org/10.22456/1982-6524.71186

PELLEGRINO, Sílvia P. 2008. Imagense Substâncias como Vínculos de Pertencimento: as experiências Wajãpie Yanomami. São Paulo, tese de doutorado, Universidade de São Paulo. DOI: https://doi. org/10.11606/T.8.2009.tde-23042009-151512

PENFIELD, Amy. 2017. Dodged debts and the submissive predator: perspectives on Amazonian relations of dependence. Journal of The Royal Anthropological Institute, v. 23, n. 2: 320337. DOI: https://doi.org/10.1111/1467-9655.12609

PERRONE-MOISÉS, Beatriz. 2015. Festa e guerra. São Paulo, tese de LivreDocência, Universidade de São Paulo.

PESQUISADORES WAJÃPI. 2008. l'ã: Para nós não existe só "imagem". Disponível em: http://www.apina.org.br/documentos/laPara_nos_nao_existe_so_imagem.pdf PESQUISADORES WAJÃPI. 2009. Jane Reko Mokasia: Organização Social Wajãpi. 2. ed. Rio de Janeiro, Museu do Índio.

PETERSON, Nicolas. 1993. Demand Sharing: Reciprocity and the Pressure for Generosity among Foragers". American Anthropologist, v. 95, n. 4: 860-874. DOI: https://doi. org/10.1525/aa.1993.95.4.02a00050

PETERSON, Nicolas. 2013. On the persistence of sharing: personhood, asymmetrical reciprocity, and demand sharing in the Indigenous Australian domestic moral economy. The Australian Journal of Anthropology, v. 24, n. 2: 166-176. DOI: https://doi.org/10.1111/taja.12036

STRATHERN, Marilyn. 1999. "Divisions of Interest and Languages of Ownership". In: STRATHERN, Marilyn. Property, substance and effect: anthropological essays on persons and things. New Brunswick: The Athlone Press, pp. 136-158. 
artigo | Camila Galan de Paula | Assimetria e saliência: a relação entre iniciador/a e imitadores/as na circulação de bens industrializados entre os Wajãpi no Amapá

STRATHERN, Marilyn. 2006. Ogênero da dádiva: problemas com as mulherese problemas com a sociedade na Melanésia. Campinas, Ed. da Unicamp.

SWAINE, Michael D.; WHITMORE, Timothy. C. 1988. On the definition of ecological species groups in tropical rain forests. Vegetatio, v. 75, n. 1-2: 81-86. https://www.jstor.org/stable/20038279

SZTUTMAN, Renato. 2005. O profeta e o principal: a ação política ameríndia e seus personagens. São Paulo, tese de doutorado, Universidade de São Paulo.

TINOCO, Sílvia. L. S. M. 2000. Joviña, cacique, professor e presidente: as relações entre 0 conselho Apina e os cursos de formação de professores Waiãpi. São Paulo, dissertação de mestrado, Universidade de São Paulo. DOI: https://doi.org/10.11606/D.8.2000. tde-12032003-083603

VAN VELTHEM, Lúcia H. 2002. "Feitos por inimigos': Os brancos e seus bens nas representações Wayana do contato". In: ALBERT, Bruce; RAMOS, Alcida (org.). Pacificando o branco: cosmologias do contato no Norte-Amazônico. São Paulo: Editora da UNESP; Imprensa Oficial; IRD, pp. 61-78.

VAN VELTHEM, Lúcia H. 2010. Os "originais" e os "importados": referências sobre a apreensão wayana dos bens materiais. Indiana, v. 27: 141-159. DOI: https:// doi.org/10.18441/ind.v27io.141-159
VANZOLINI, Marina. 2018. O feitiço e a feitiçaria capitalista. Revista do Instituto de Estudos Brasileiros, v. 69: 324-337. DOI: https://doi. org/10.11606/issn.2316-901X.voi69p324-337

VIVEIROS DE CASTRO, Eduardo. 1986. Araweté: os deuses canibais, Rio de Janeiro, J. Zahar Editor; ANPOCS.

VIVEIROS DE CASTRO, Eduardo. 2004. Perspectival Anthropology and the Method of Controlled Equivocation. Tipití: Journal of the Society for the Anthropology of Lowland South America, v. 2, n. 1: 1-21. https:// digitalcommons.trinity.edu/tipiti/vol2/iss1/1

VIVEIROS DE CASTRO, Eduardo. 2006. A inconstância da alma selvagem: e outros ensaios de antropologia. São Paulo, Cosac Naify.

VIVEIROS DE CASTRO, Eduardo. 2011. "O intempestivo, ainda". In: CLASTRES, Pierre. Arqueologia da violência: pesquisa de antropologia política. 2 ed. São Paulo, Cosac Naify, pp. 297-361. (Posfácio).

WALKER, Harry. 2013. Wild Things: Manufacturing Desire in the Urarina Moral Economy. The Journal of Latin American and Caribbean Anthropology, v. 18, n. 1: 51-66. DOI: https://doi.org/10.1111/j.1935-4940.2012.01254.X

WASHBURN, Dorothy. 1999. Perceptual Anthropology: The Cultural Salience of Symmetry. American Anthropologist, v. 101, n. 3: 547-562. DOI: https://doi. org/10.1525/aa.1999.101.3.547

Recebido em 27 de janeiro de 2020. Aceito em 9 de dezembro de 2020. 